\title{
Biocompatibility of titanium surface nanostructures following chemical processing and heat treatment
}

\author{
Miho Fujio' ${ }^{1}$, Satoshi Komasa ${ }^{1 *}$, Hiroshi Nishizaki ${ }^{1}$, Tohru Sekino ${ }^{2}$ and Joji Okazaki ${ }^{1}$ \\ ${ }^{1}$ Department of Removable Prosthodontics and Occlusion, Osaka Dental University, 8-1 Kuzuha-hanazono-cho, Hirakata, Osaka 573-1121, Japan \\ ${ }^{2}$ The institute of Scientific and Industrial Research, Osaka University, 8-1 Mihogaoka, Ibaraki, Osaka 567-0047, Japan
}

\begin{abstract}
The aims of the present study were to investigate alkali and heat treatment of titanium surfaces, and to evaluate the ability of such modified surfaces to improve osteogenic differentiation of rat bone marrow (RBM) cells to increase the success rate of titanium implants. To improve bone differentiation on titanium alloy implants, titania nanosheet (TNS) structures were fabricated on titanium surfaces by $\mathrm{NaOH}$ and heat treatment at $200,400,600$, and $800^{\circ} \mathrm{C}$. Cell behavior on heattreated TNS-modified titanium was investigated, and the ability of the modified surfaces to affect osteogenic differentiation of RBM cells and to increase the success rate of titanium implants was evaluated. The nanoscale network structures formed by alkali etching markedly enhanced the cell adhesion and osteogenesis-related gene expression of RBM cells. Other cell behaviors, such as proliferation, alkaline phosphatase activity, osteocalcin deposition, and mineralization, were also markedly increased on heat-treated TNS-modified titanium. Our results suggest that nanostructure-modified titanium implants promote osteogenic differentiation, which may improve biointegration of these implants into alveolar bone.
\end{abstract}

\section{Introduction}

Titanium is widely used in bioactive materials, usually as a bone substitute, even under high-load conditions. However, because titanium cannot directly bond to bone, titanium surfaces are usually modified to enhance bone formation around implants. Vandrovcova et al. [1] have recently reviewed the growing evidence demonstrating that surface-modified materials are highly effective for adhesion, growth, and osteogenic differentiation of cells.

The structures used in this study, called titanium nanosheets (TNS), are nanostructures similar to the $\mathrm{TiO}_{2}$ (titania) nanotubes created by titanium and titanium alloy deposition using $\mathrm{TiO}_{2}$ sputtering $[2,3]$. Recently, it was shown that titania nanotubes and TNS structures can be formed on titanium metal surfaces by treatment in $10 \mathrm{M} \mathrm{NaOH}$ aqueous solution at $30^{\circ} \mathrm{C}$. Treatment with $\mathrm{NaOH}$ aqueous solution has been shown to produce a rough, nanoscale surface. A previous study reported that TNS produced via chemical processing promote the osteogenic differentiation of rat bone marrow (RBM) cells [2-4]. The surface properties and structures of materials play important roles in the adsorption of proteins, which can influence cell behavior. However, morphological fixation of an implant to bone, essentially a mechanical fixation [5], requires a long immobilization time and may ultimately result in loosening at the bone-implant interface. To achieve chemical bonding of the implant with bone, the titanium surface is often coated with a hydroxyapatite layer, using alkali and heat treatment [6].

Recently, methods of inducing bioactivity for direct bone-implant bonding, using chemical modification of the biomaterial surface, have been widely studied. Kim et al. introduced alkali and heat treatments for surface modification of titanium alloys to improve bioactivity [7]. Several researchers have reported that a stable sodium titanate hydrogel layer was formed on the titanium surface during heat treatment following alkali treatment [8-11]. If this method could be applied to TNS-modified Ti surfaces, it could produce a very stable implant surface.

The aims of the present study were to investigate alkali and heat treatment of Ti surfaces, and to evaluate the ability of such modified surfaces to induce osteogenic differentiation of RBM cells to increase the success rate of titanium implants. TNS structures on disks were modified by $\mathrm{NaOH}$ treatment followed by heat treatment, and their morphology and biocompatibility were assessed.

\section{Materials and methods}

\section{Sample preparation}

Titanium samples (JIS Grade 2) treated with $\mathrm{NaOH}$ to form TNSs on their surfaces were used as the experimental material. Unprocessed titanium disks ( $\mathrm{Ti}$ ) were used as controls. Ti disks (15 $\mathrm{mm}$ in diameter) were punched from sheets of 1-mm-thick titanium (Daido Steel, Osaka, Japan). The disks were immersed in $10 \mathrm{M}$ aq. $\mathrm{NaOH}$ and maintained at $30^{\circ} \mathrm{C}$ for $24 \mathrm{~h}$. After alkali treatment, the samples were placed in an electrical furnace and heated to $200,400,600$, or $800^{\circ} \mathrm{C}$ at a heating rate of $5^{\circ} \mathrm{C} / \mathrm{min}$ under an air atmosphere. The solution in each flask was replaced with distilled water $(200 \mathrm{~mL})$ until the solution reached a conductivity of $5 \mu \mathrm{S} / \mathrm{cm}$. Samples were then dried at room temperature.

\section{Characterization of materials}

The surface topography of the samples was qualitatively

Correspondence to: Satoshi Komasa, Department of Removable Prosthodontics and Occlusion, Osaka Dental University, 8-1 Kuzuha-hanazono-cho, Hirakata, Osaka 573-1121, Japan, Tel: +81-72-864-3084, Fax: +81-72-864-3184, E-mail: komasa-s@cc.osaka-dent.ac.jp

Key words: implant, nanostructure, rat MSC

Received: January 04, 2017; Accepted: January 19, 2017; Published: January 23 , 2017 
evaluated by scanning electron microscopy (SEM, S-4000, Shimadzu, Kyoto, Japan) and scanning probe microscopy (SPM; SPM-9600, Shimadzu). The composition of the coating was analyzed by X-ray photoelectron spectroscopy (XPS; Kratos Analytical Axis ultra DLD electron spectrometer, Kratos Instruments, Manchester, UK) using a monochromatic $\mathrm{Al} \mathrm{Ka} \mathrm{X-ray} \mathrm{source.} \mathrm{Each} \mathrm{sample} \mathrm{was} \mathrm{etched} \mathrm{with}$ argon ions for $2 \mathrm{~min}$ (evaporation rate of $5 \mathrm{~nm} / \mathrm{min}$ ) to remove surface contaminants. The surface phase properties were investigated using thin-film X-ray powder diffractometry (TF-XRD) (RINT-2500, Rigaku Co., Tokyo, Japan). Spectra were recorded in the range of $2 \Theta=20^{\circ}$ $50^{\circ}$, operating at $50 \mathrm{kV}$ and $300 \mathrm{~mA}$, using a $\mathrm{Cu}-\mathrm{Ka}$ radiation source, a scanning speed of $2^{\circ} / \mathrm{min}$, and an incident angle of $1^{\circ}$. Contactangle measurements were performed using a video contact-angle measurement system (VSA 2500 XE, AST Products, Tokyo, Japan) at room temperature. Ultrapure water was used in contact-angle measurements.

\section{Protein adsorption assay}

Bovine serum albumin (BSA), fraction V (Pierce Biotechnology, Rockford, IL) was used as a model protein. Protein solution (300 $\mu \mathrm{L}, 1 \mathrm{mg} / \mathrm{mL}$ protein in saline) was pipetted onto each sample. After incubation for $1,3,6$, or $24 \mathrm{~h}$ at $37^{\circ} \mathrm{C}$, nonadherent proteins were removed and mixed with bicinchoninic acid (Pierce Biotechnology) at $37^{\circ} \mathrm{C}$ for $1 \mathrm{~h}$. The amount of albumin removed and the total amount of albumin inoculated were quantified using a microplate reader at 562 $\mathrm{nm}$. The rate of albumin adsorption was calculated as the percentage of albumin adsorbed on samples relative to the total amount of albumin in solution.

\section{Cell culture}

RBM cells were isolated from the femurs of 7-week-old SpragueDawley rats. This study was performed according to the Guidelines for Animal Experimentation at Osaka Dental University (Approval No. 16-05001). Briefly, rats were euthanized using $4 \%$ isoflurane, and the bones were aseptically excised from the hind limbs. The proximal end of the femur and the distal end of the tibia were clipped. A 21-gauge needle (Terumo, Tokyo, Japan) was inserted into the hole in the knee joint of each bone, and the marrow was flushed from the shaft with culture medium (Eagle's minimal essential medium; Wako Pure Chemical Industries, Ltd., Osaka, Japan) supplemented with 10\% fetal bovine serum (FBS; Invitrogen, Life Technologies Co., Carlsbad, CA, USA), penicillin $(500 \mathrm{U} / \mathrm{mL}$ ) (Cambrex Bio Science Walkersville Inc., Walkersville, MD, USA), streptomycin $(500 \mu \mathrm{g} / \mathrm{mL})$ (Cambrex Bio Science Walkersville Inc.), and Fungizone $(1.25 \mu \mathrm{g} / \mathrm{mL})$ (Cambrex Bio Science Walkersville Inc.). The resulting marrow pellet was dispersed by trituration, and the cell suspensions from all bones were combined in a centrifuge tube. RBM cells were cultured in $75-\mathrm{cm}^{2}$ culture flasks (Falcon, Becton Dickinson Labware, NJ, USA) in culture medium.

At confluence, cells were removed from flasks by trypsinization, washed twice with phosphate-buffered saline (PBS; Dulbecco's Formula Modified, ICN Biochemicals, England), resuspended in culture medium and seeded at a cell density of $4 \times 10^{4} \mathrm{cells} / \mathrm{cm}^{2}$ into 24 well tissue culture plates (Falcon) containing test or control titanium disks. The cells were cultured at $37^{\circ} \mathrm{C}$ in a humidified $5 \% \mathrm{CO}_{2} / 95 \%$ air atmosphere.

\section{Cell adhesion}

Cell adhesion was measured using the CellTiter-Blue Cell Viability Assay (Promega, Madison, WI, USA) according to the manufacturer's protocol. RBM cells were seeded on the samples at a density of $4 \times 10^{4}$ cells $/ \mathrm{cm}^{2}$ and allowed to attach for $1,3,6$, or $24 \mathrm{~h}$. At each prescribed time point, nonadherent cells were removed by rinsing with PBS. CellTiter-Blue Reagent $(50 \mu \mathrm{L})$ and PBS $(250 \mu \mathrm{L})$ were then added to each well. After incubation at $37^{\circ} \mathrm{C}$ for $1 \mathrm{~h}$, the solution was removed from the 24-well tissue culture plates (Falcon) and $100 \mu \mathrm{L}$ was added to a new 96-well tissue culture plate (Falcon). The OD 560/590 of the remaining solution was measured. The difference between the two optical densities was defined as the proliferation value.

\section{Alkaline phosphatase (ALP) activity}

After 7 or 14 days of culture, cells were washed with PBS, lysed with Triton X-100 (Sigma, St. Louis, MO, USA, 0.2\%, $200 \mu \mathrm{L}$ ) and the lysate was transferred to a microcentrifuge tube containing a $5-\mathrm{mm}$ hardened steel ball. Tubes were agitated on a shaker (Mixer Mill Type MM 301, Retsh Gmbh \& Co., Haan, Germany) at $29 \mathrm{~Hz}$ for 20 $s$ to homogenize each sample. ALP activity was measured using the Alkaline Phosphatase Luminometric ELISA Kit (Sigma) according to the manufacturer's protocol. The reaction was terminated with 3 $\mathrm{N} \mathrm{NaOH}$ to a final concentration of $0.5 \mathrm{~N} \mathrm{NaOH}$ and p-nitrophenol production was measured by absorbance at $405 \mathrm{~nm}$ using a 96-well microplate reader (SpectraMax ${ }^{\circledR}$ M5, Molecular Device Inc., Sunnyvale, CA, USA). DNA content was measured using the PicoGreen dsDNA Assay Kit (Invitrogen) according to the manufacturer's protocol. To normalize ALP activity, the amount of ALP was normalized to the amount of DNA in the cell lysate.

\section{Osteocalcin ELISA analysis}

The sandwich enzyme immunoassay used in this study is specific for rat osteocalcin (OCN) and can measure its levels directly in cell culture supernatant after 21 or 28 days of culture. The OCN levels in the cell-culture supernatant were measured using a commercial ELISA kit (Rat Osteocalcin ELISA Kit DS, DS Pharma Biomedical Co., Ltd., Osaka, Japan) according to the manufacturer's instructions.

\section{Mineralization}

Calcium deposition in the extracellular matrix was measured after dissolution with $10 \%$ formic acid. The amount of calcium was quantified using a Calcium E-test Kit (Wako Pure Chemical Industrials Ltd.). After 21 or 28 days of culture, Calcium E-Test reagent $(1 \mathrm{~mL})$ and kit buffer $(2 \mathrm{~mL})$ were added to the collected medium $(50 \mu \mathrm{L})$, and the absorbance of the reaction products was measured at $610 \mathrm{~nm}$ using a 96-well microplate reader (SpectraMax ${ }^{\circledR}$ M5). The concentration of calcium ions was calculated from the absorbance value relative to a standard curve.

\section{Statistical analysis}

All experiments were performed in triplicate. All data are reported as the mean \pm standard deviation. In all analyses, statistical significance was determined by a paired two-tailed Student's t-test. A P-value $\leq 0.05$ was considered to indicate statistical significance.

\section{Results}

\section{Sample preparation}

SEM analysis of the Ti surfaces after modification in $\mathrm{NaOH}$ at $30^{\circ} \mathrm{C}$ revealed formation of a nanoscale network structure. Figure 1 shows SEM images of the $\mathrm{NaOH}$-treated titanium surfaces subjected to heat treatment at various temperatures; a porous network structure, similar to that observed by Pattanayak et al., was observed [12]. The surface morphology and roughness of the TNS samples were examined 


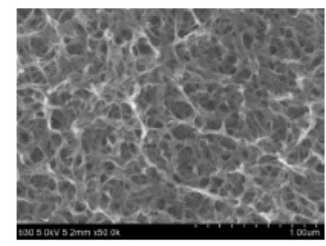

A

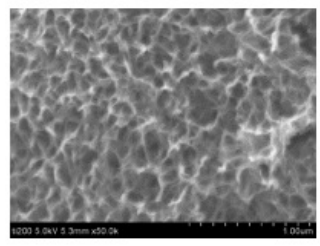

AH200

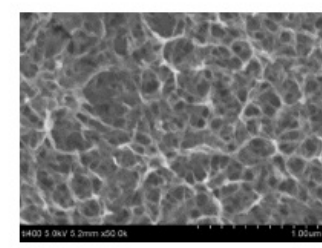

AH400

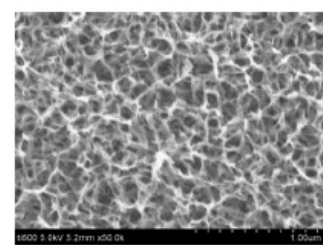

AH600

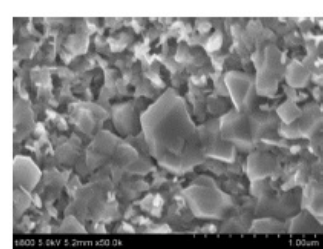

AH800

Figure 1. SEM images of the specimens subjected to alkali treatment with $10 \mathrm{M} \mathrm{NaOH}$ solution (A), and alkali-heat treatment $(\mathrm{AH})$ performed various heating temperatures at $200^{\circ} \mathrm{C}, 400^{\circ} \mathrm{C}$, $600^{\circ} \mathrm{C}, 800^{\circ} \mathrm{C}$.

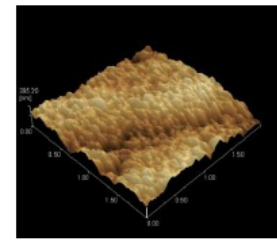

A

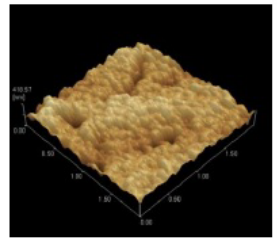

AH200

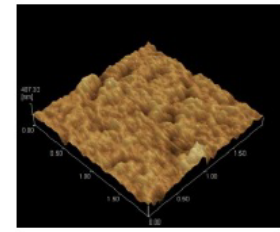

AH400

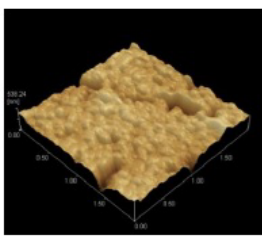

AH600

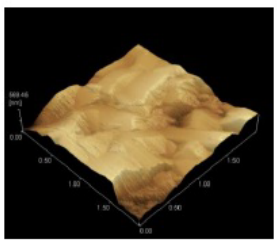

AH800

Figure 2: SPM images of the specimens subjected to alkali treatment with $10 \mathrm{M} \mathrm{NaOH}$ solution (A), and alkali-heat treatment $(\mathrm{AH})$ performed various heating temperatures at $200^{\circ} \mathrm{C}, 400^{\circ} \mathrm{C}$, $600^{\circ} \mathrm{C}, 800^{\circ} \mathrm{C}$.

by SPM; the results are shown in Figure 2. Porous network structures were observed. Changes in surface roughness (Ra) are shown in Table 1. Surface roughness was not significantly different before and after heat treatments performed at $200-600^{\circ} \mathrm{C}$, but sharply increased after treatment at $800^{\circ} \mathrm{C}$, which produced a prismatic layer containing crystals. Figure 3 shows the results of XPS surface chemical analysis of Ti after samples were subjected to alkali treatment in a $10 \mathrm{M} \mathrm{NaOH}$ solution at $30^{\circ} \mathrm{C}$, and subsequent alkali-heat treatment at different heating temperatures. There were no significant differences in the XPS spectra of the specimens before and after heat treatments performed at $200-600^{\circ} \mathrm{C}(\mathrm{Ti}, \mathrm{O})$, but no Na peak was observed. Figure 4 shows the TFXRD patterns of the surfaces of the $\mathrm{NaOH}$-treated Ti surfaces subjected to heat treatment at various temperatures. The main diffraction peaks were assigned as reported in the study by Kim et al. The gel layer began to precipitate crystalline sodium titanate and rutile at approximately $600^{\circ} \mathrm{C}$ and was fully crystalized above $800^{\circ} \mathrm{C} \mathrm{[6].} \mathrm{Cross-sectional} \mathrm{views}$ of water droplets on the surfaces of treated and control disks and their contact angles are depicted in Figure 5. Test and control disks showed marked differences in contact angles.
Table 1.Surface roughness of the specimens subjected to alkali treatment (A30) and alkaliheat treatments $(\mathrm{AH})$ under various subsequent heating temperatures.

\begin{tabular}{|c|c|}
\hline & Ra (nm) \\
\hline A & 17.389 \\
\hline AH200 & 19.278 \\
\hline AH400 & 18.428 \\
\hline AH600 & 19.384 \\
\hline AH800 & 145.28 \\
\hline
\end{tabular}

\section{Protein adsorption}

The amount of BSA protein adsorbed on sample surfaces after 1, 3,6 , or $24 \mathrm{~h}$ of incubation was assayed (Figure 6). More protein was adsorbed onto the alkali-treated samples than controls.

\section{Cell adhesion and proliferation}

Cell adhesion on the titanium disks was assessed after 1, 3, 6, or 24 $\mathrm{h}$ of incubation (Figure 7). Alkali-treated and control samples differed significantly in cell adhesion after $1,3,6$, and $24 \mathrm{~h}$. 


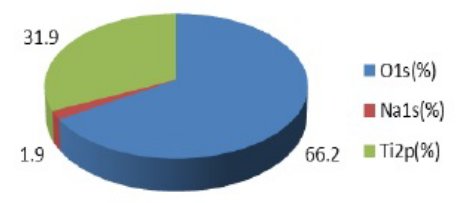

A

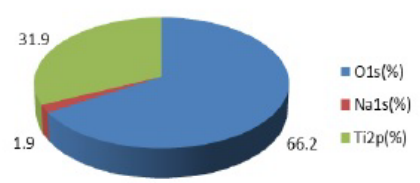

AH200

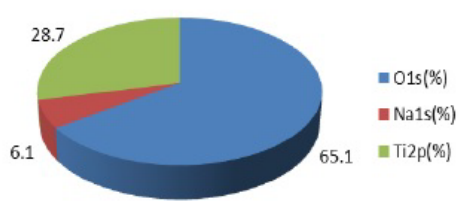

AH400

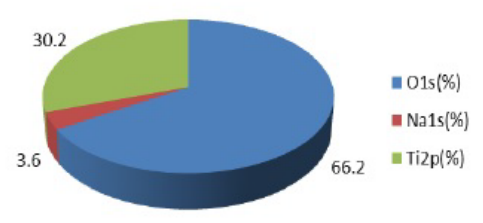

AH600

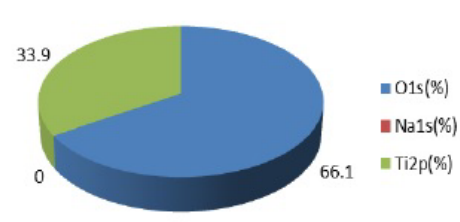

AH800

Figure 3: Atomic concentration of to alkali treatment with $10 \mathrm{M} \mathrm{NaOH}$ solution (A), and alkali-heat treatment (AH) performed various heating temperatures at $200^{\circ} \mathrm{C}, 400^{\circ} \mathrm{C}, 600^{\circ} \mathrm{C}, 800^{\circ} \mathrm{C}$ by XPS analysis.

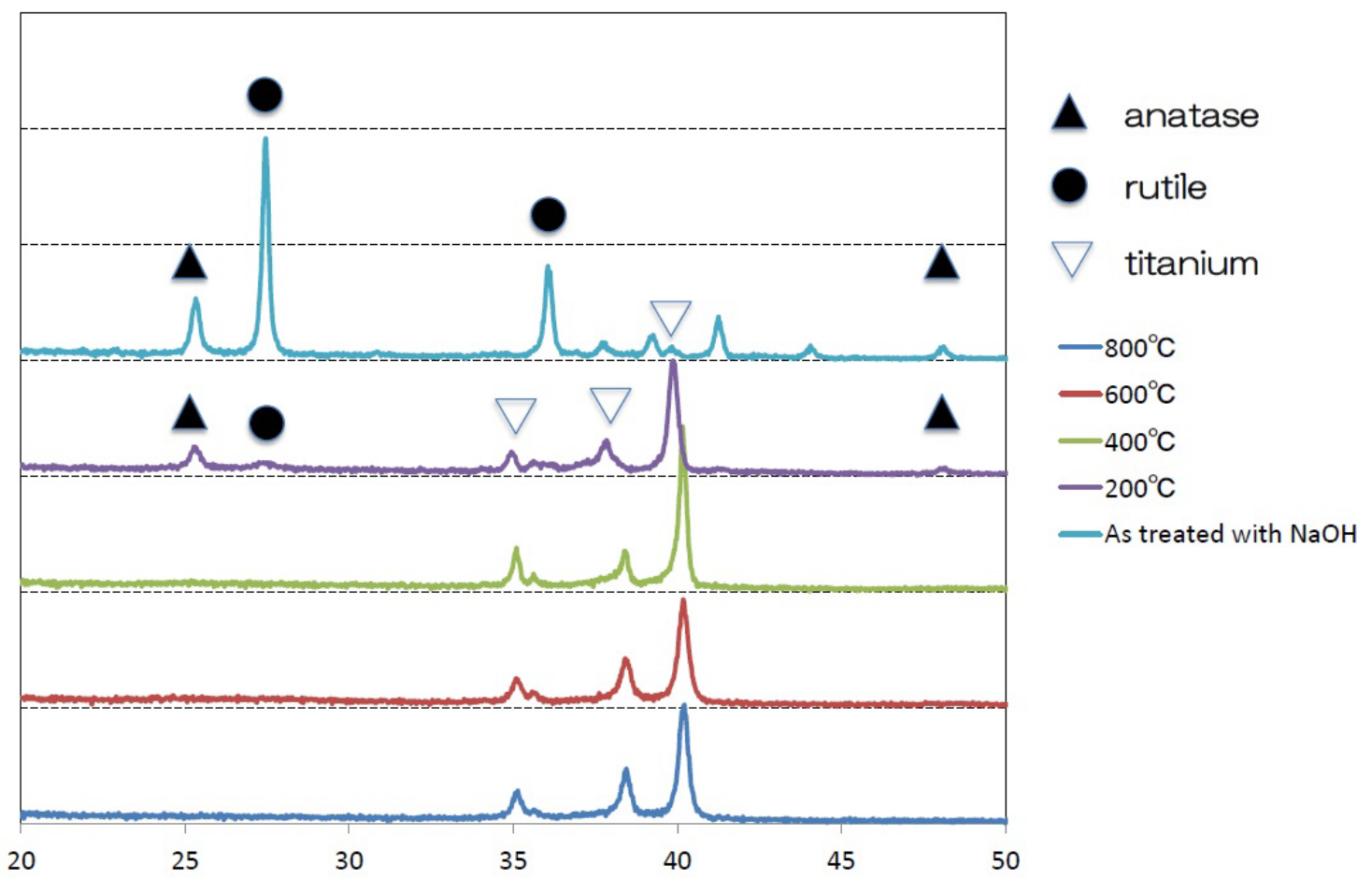

Figure 4: TF-XRD patterns of the surfaces of the $\mathrm{NaOH}$-treated titanium surfaces subjected to heat treatments at various temperatures.

\section{ALP activity}

Cell differentiation was assessed by measuring the activity of the differentiation marker ALP in the test and control groups after 7 and 14 days. At both time points, ALP activity was significantly higher in the test group cells than in the control group cells (Figure 8).

\section{Osteocalcin production}

Figure 9 shows the production of OCN in the test and control groups after 21 and 28 days. The OCN content was significantly higher in the test group than in the control group.

\section{Mineralization}

Calcium deposition in the extracellular matrix of RBM cells in the test and control groups after 21 and 28 days is illustrated in Figure 10. $\mathrm{Ca}$ deposition in the culture wells was cumulative, and measured levels typically increased with exposure time. Significantly more calcium was deposited by cells in the test group after both periods than by cells in the control group.

\section{Discussion}

This study investigated whether RBM cells respond differently to 


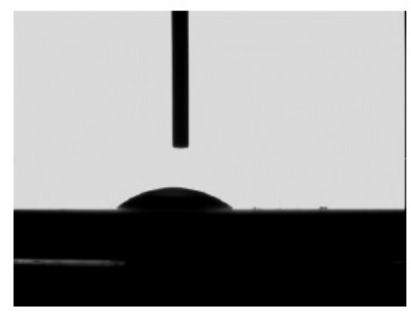

A

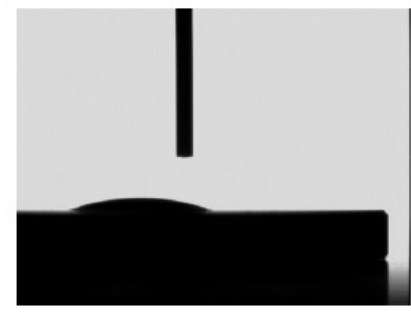

AH200

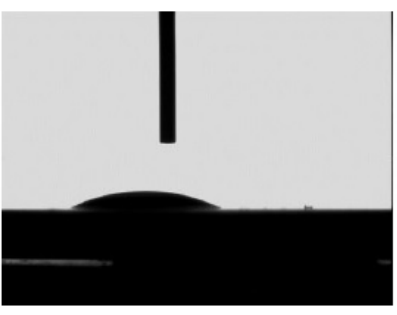

AH400

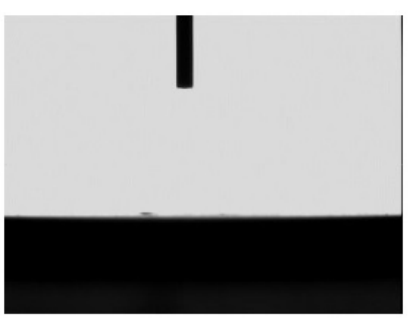

AH600

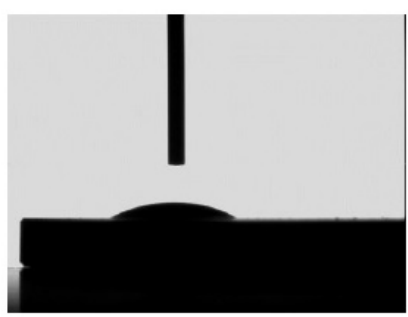

AH800

Figure 5: Cross-sectional view of a water droplet at alkali treatment with $10 \mathrm{M} \mathrm{NaOH}$ solution (A), and alkali-heat treatment $(\mathrm{AH})$ performed various heating temperatures at $200^{\circ} \mathrm{C}, 400^{\circ} \mathrm{C}$, $600^{\circ} \mathrm{C}, 800^{\circ} \mathrm{C}$.

$1 \mathrm{~h}$
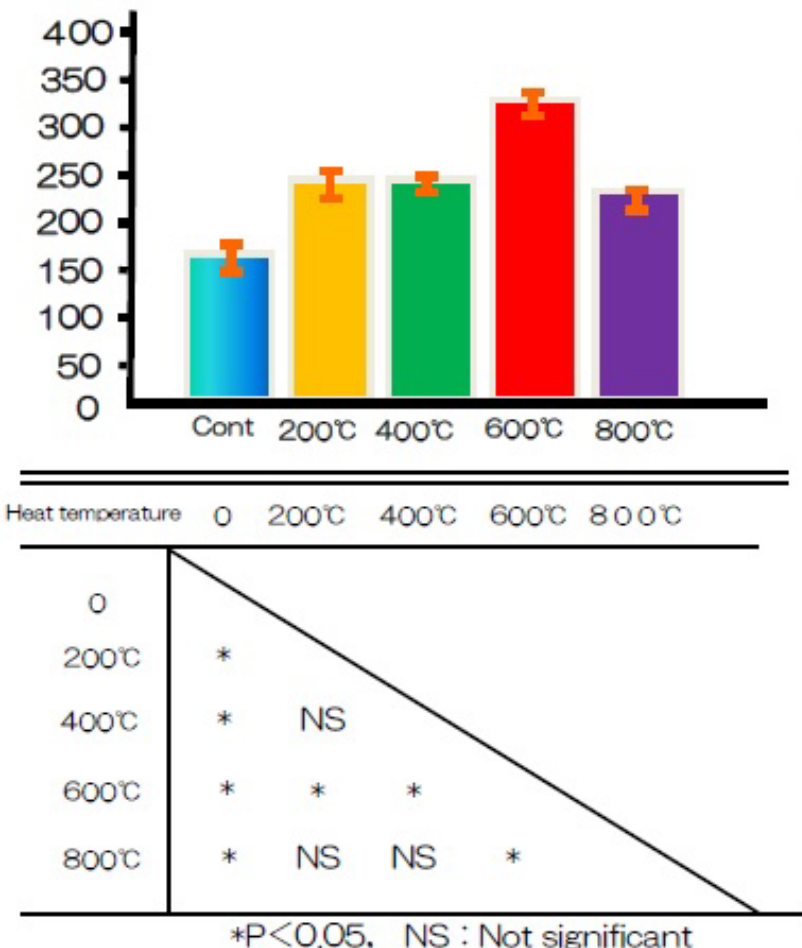

3h
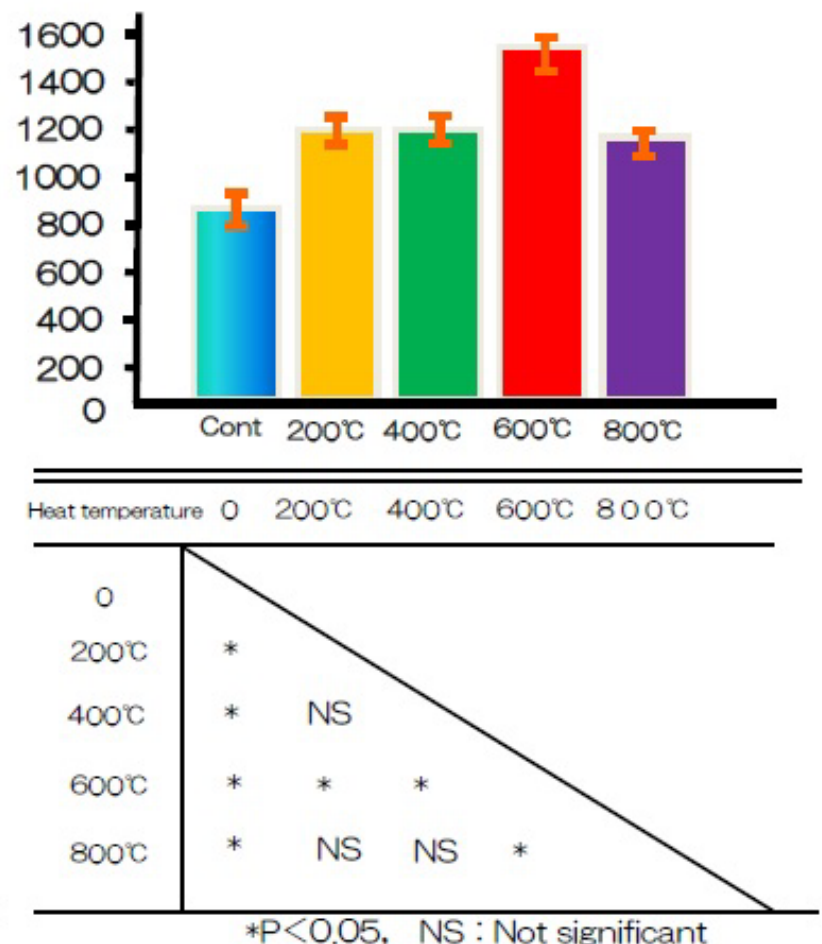

Figure 6: Albumin adhesion at alkali treatment with $10 \mathrm{M} \mathrm{NaOH}$ solution, and alkali-heat treatment performed various heating temperatures at $200^{\circ} \mathrm{C}, 400^{\circ} \mathrm{C}, 600^{\circ} \mathrm{C}, 800^{\circ} \mathrm{C}$ 
$6 \mathrm{~h}$

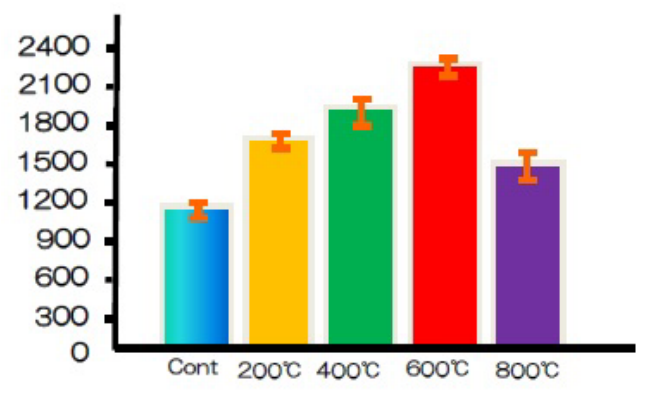

Heat temperature $0200^{\circ} \mathrm{C} \quad 400^{\circ} \mathrm{C} \quad 600^{\circ} \mathrm{C} 800^{\circ} \mathrm{C}$

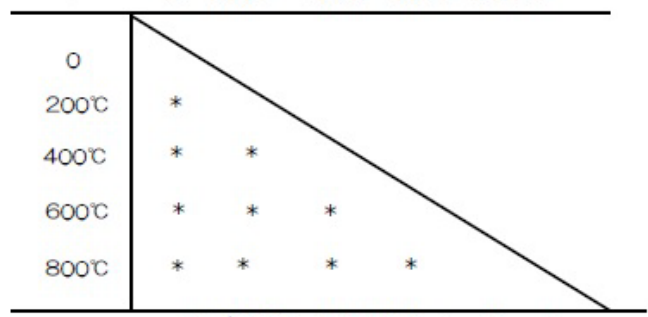

$* \mathrm{P}<0.05, \quad$ NS : Not significant
$24 h$
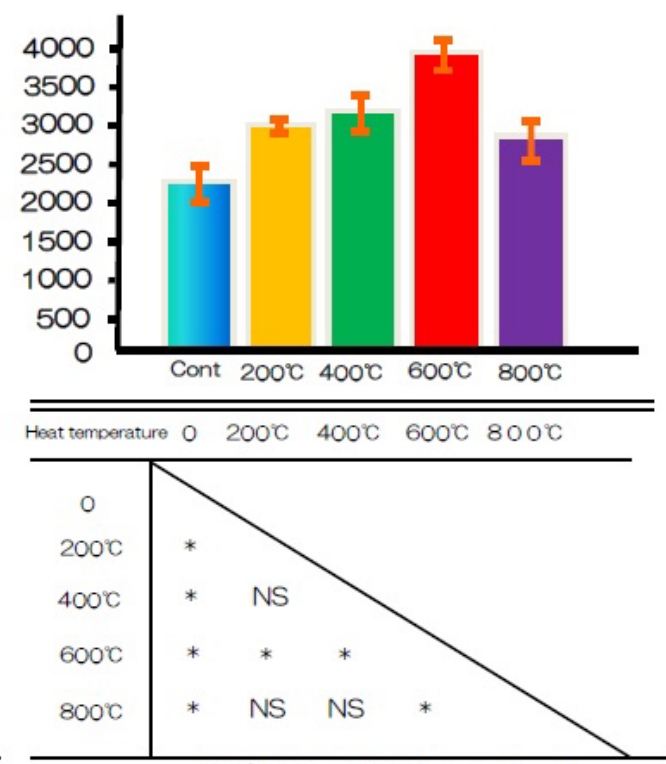

$* \mathrm{P}<0.05, \quad$ NS : Not significant

$1 \mathrm{~h}$

3h
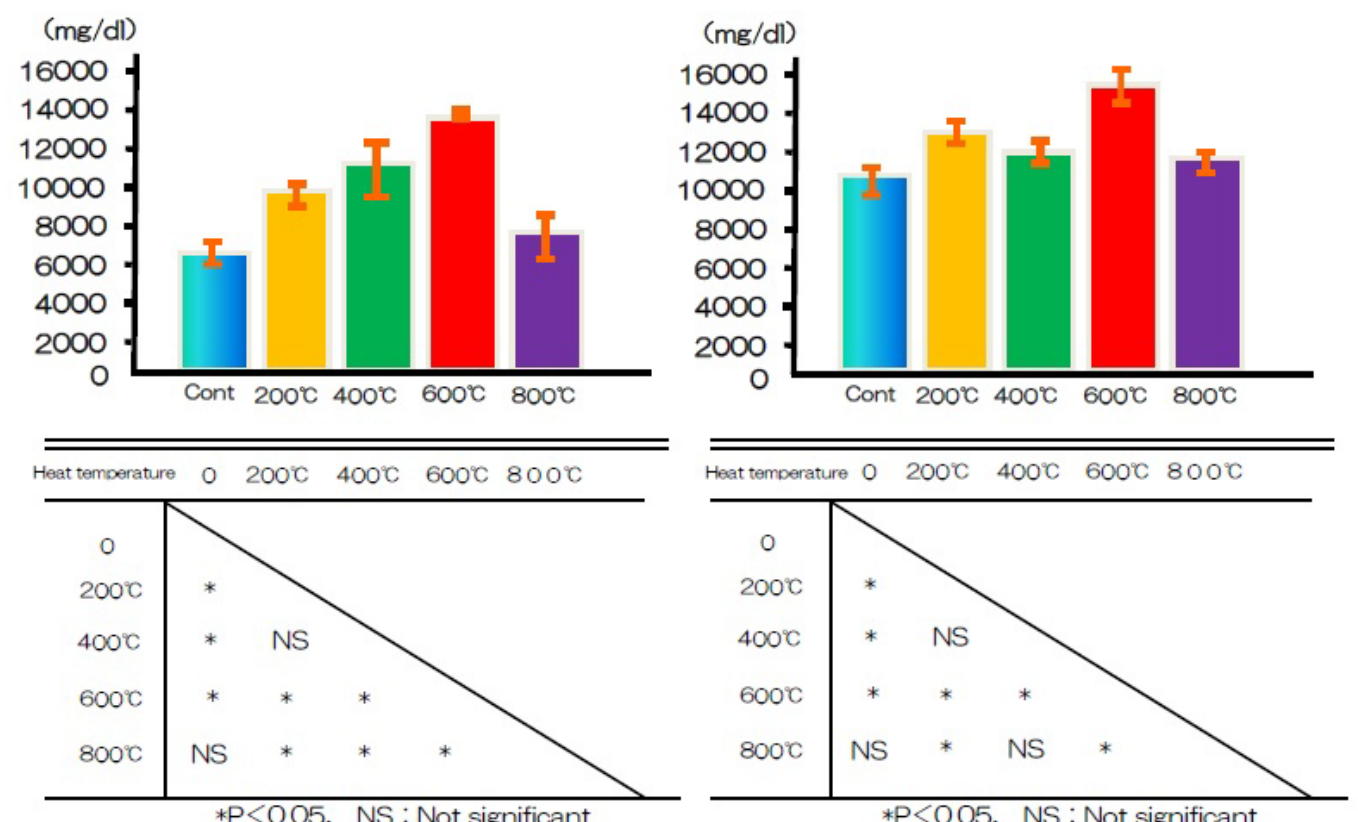

Figure 7: BMMSCs adhesion at alkali treatment with $10 \mathrm{M} \mathrm{NaOH}$ solution, and alkali-heat treatment performed various heating temperatures at $200^{\circ} \mathrm{C}, 400^{\circ} \mathrm{C}, 600^{\circ} \mathrm{C}, 800^{\circ} \mathrm{C}$.

titanium implants subjected to chemical and heat treatment surface modification than to unmodified implants. $\mathrm{NaOH}$ treatment and heat treatment at $600^{\circ} \mathrm{C}$ stabilized a mechanically strong, essentially amorphous sodium titanate layer containing a small amount of crystalline sodium titanate and a rutile layer. We found that initial adhesion of cells and RBM cell differentiation markers, such as ALP and OCN, was elevated in samples containing titanium disks modified by alkali and heat treatment compared with those containing an unmodified, polished titanium disk. We also found that calcium deposition in the extracellular matrix of RBM cells was higher in the presence of titanium disks modified by alkali and heat treatment compared with unmodified control disks. Our results suggest that 

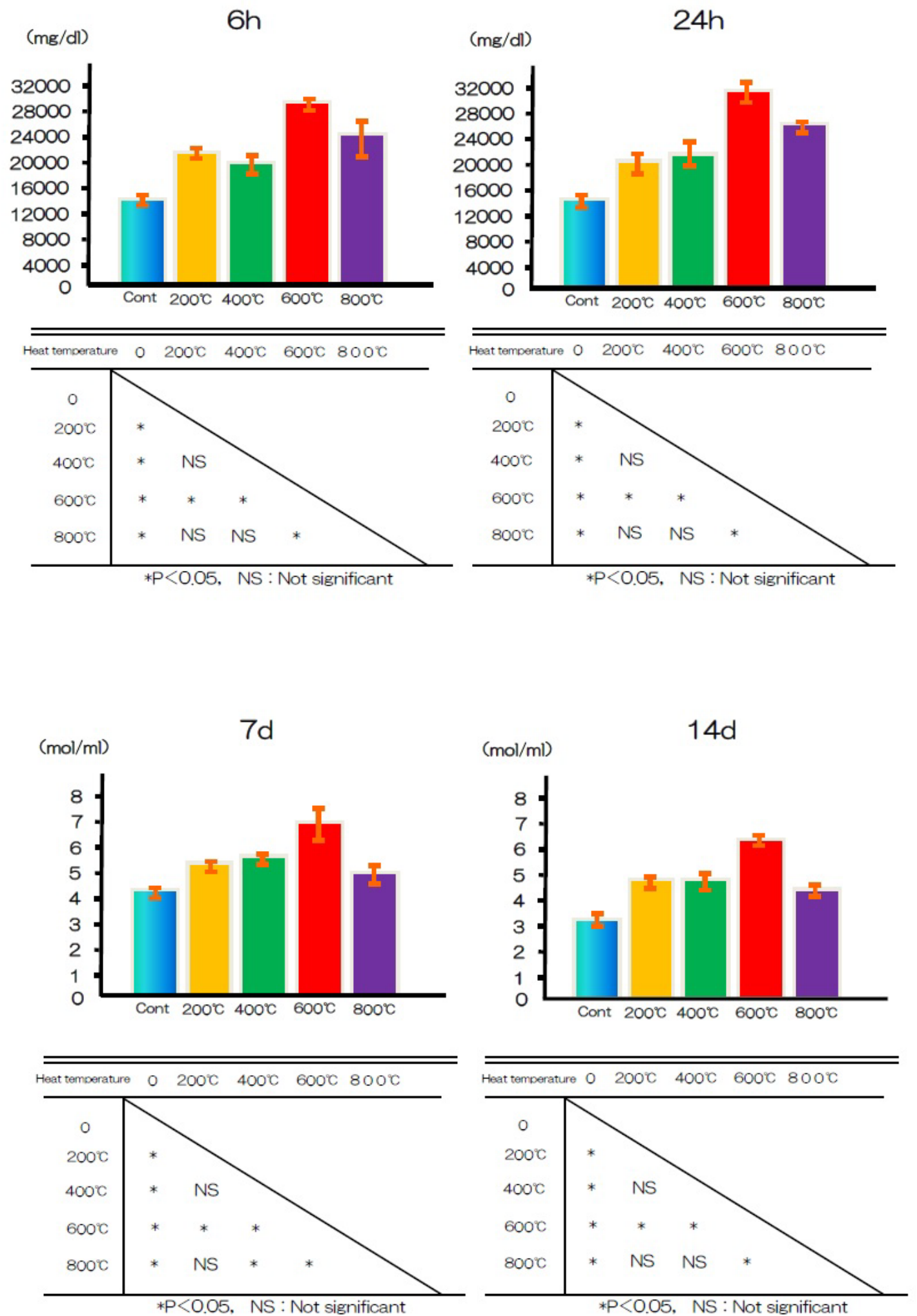

Figure 8: ALP activity at alkali treatment with $10 \mathrm{M} \mathrm{NaOH}$ solution, and alkali-heat treatment performed various heating temperatures at $200^{\circ} \mathrm{C}, 400^{\circ} \mathrm{C}, 600^{\circ} \mathrm{C}, 800^{\circ} \mathrm{C}$. 

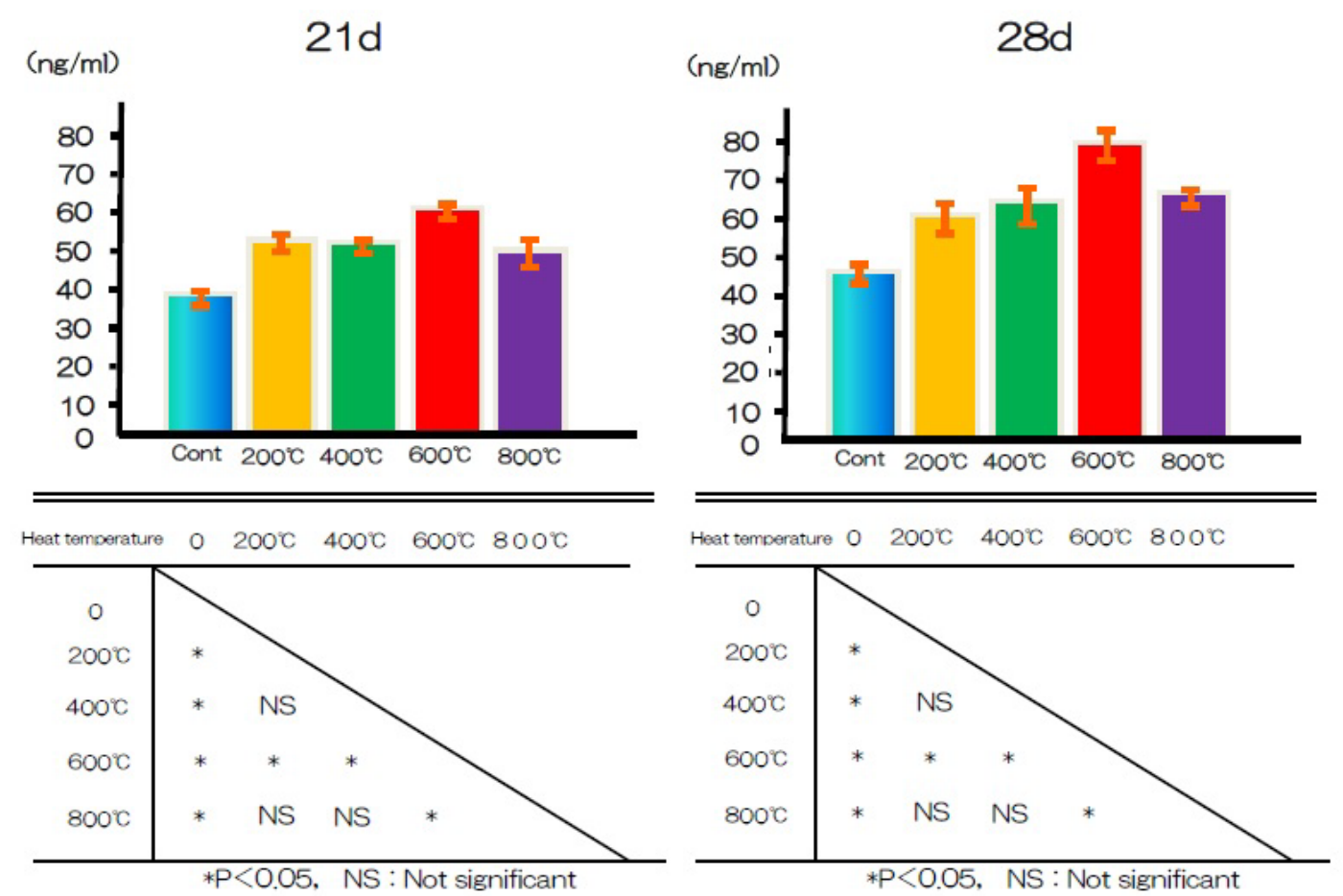

Figure 9: $\mathrm{OCN}$ production at alkali treatment with $10 \mathrm{M} \mathrm{NaOH}$ solution, and alkali-heat treatment performed various heating temperatures at $200^{\circ} \mathrm{C}, 400^{\circ} \mathrm{C}, 600^{\circ} \mathrm{C}, 800^{\circ} \mathrm{C}$.
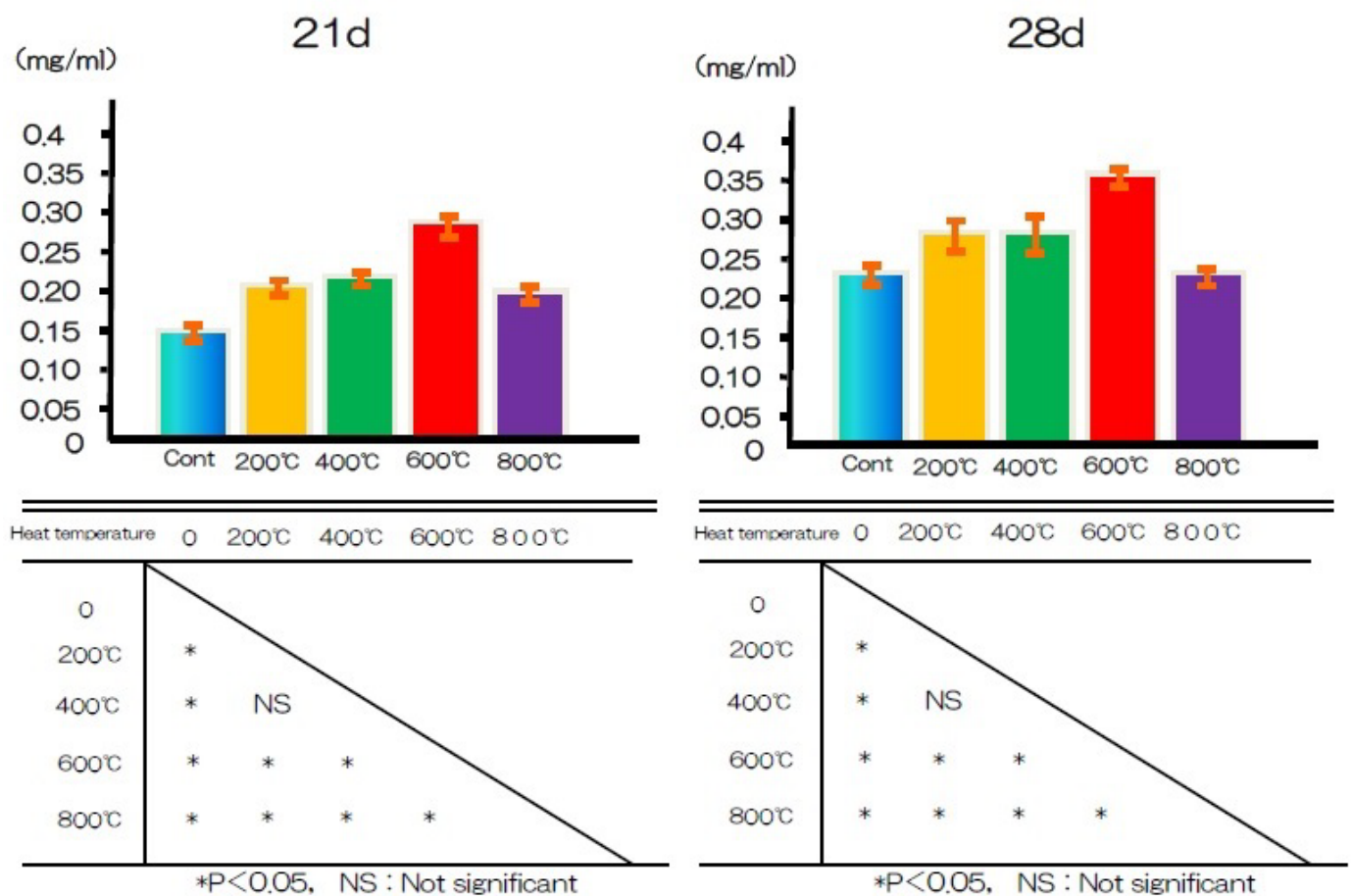

Figure 10: Ca deposition at alkali treatment with $10 \mathrm{M} \mathrm{NaOH}$ solution, and alkali-heat treatment performed various heating temperatures at $200^{\circ} \mathrm{C}, 400^{\circ} \mathrm{C}, 600^{\circ} \mathrm{C}, 800^{\circ} \mathrm{C}$.

titanium disks modified by alkali and heat treatment promote RBM cell adhesion, differentiation, and activation, thereby augmenting calcium deposition.

Titanium alloy modified by alkali and heat treatment has been reported to bond well to bone, and is thought to be clinically applicable as an implant and orthopedic material. If alkali treatment alone could produce a titanium surface with high bone bonding ability, bioactive titanium implants could be prepared using just $\mathrm{NaOH}$ solution. Kim et al. $[7,11]$ reported that titanium treated with alkali alone forms a surface apatite layer in simulated body fluid (SBF), similar to the layer formed on titanium treated with both alkali and heat; however, this layer is so unstable as to lose its apatite-forming ability during preservation 
or implantation, although it is not known at what stage the apatiteforming ability is lost. Several in vitro studies have shown that the surface layer of an alkali-treated titanium surface can be detached from its substrate by adhesive tape, and that the surface layer is mechanically weak [12-14]. Thus, combined alkali and heat treatment form a more stable alkali titanate layer [15].

The SEM images of our test disks demonstrated that the modified TNS surface has good surface roughness, without cracks. The SEM images of the TNS modified titanium alloy heated at $200-600^{\circ} \mathrm{C}$ were almost identical to the images of titanium alloy surfaces treated with alkali alone, shown in our recent study [16]. In another recent study, SEM images of alkali- and heat-modified titanium showed finer-grained surface roughness than those of titanium modified with alkali alone [3]. Our SEM analysis showed that our modified titanium surfaces had similar surface roughness to those produced in previous studies [17-18]. Ra is often used as the sole height parameter to describe implant surface roughness. Specimens subjected to heat treatment at $200-600^{\circ} \mathrm{C}$ after alkali treatment showed low Ra values, and those subjected to $800^{\circ} \mathrm{C}$ heat treatment showed higher Ra values. Combined heat and alkali treatment produced modified titanium surfaces with optimal roughness for cellular attachment. The $\mathrm{Ra}$ of the heat-treated TNS-modified titanium alloy surface was $17 \mathrm{~nm}$, which was lower than that of the titanium surface without heat treatment. The contact angles of the alkali and heat-treated titanium disks were lower than those of the control group, which suggests that the wettability of the surface of the test group was decreased by $\mathrm{NaOH}$ treatment. However, our understanding of how surface roughness and topography of modified titanium alloy surfaces affects their wettability, and further studies are needed to determine the optimal paramaters. Xing and Fujino et al., showed that a surface roughness between 13 and $16 \mathrm{~nm}$ is optimal for RBM cell culture $[4,19]$. The nanonetwork structure formed on the titanium disk here is similar to the hierarchical structure reported by Lingzhou and coworkers [20]. In their work, hierarchical nanotextured titanium alloy surface topographies with titania nanostructures that mimicked the hierarchical structure of bone tissues were produced by etching followed by anodization. Natural tissues are hierarchical structures of nanoscale building blocks assembled in an organized manner. Hierarchical structures composed of nanocomponents may provide a more suitable surface topography for bone marrow cell functions than simpler structures because they better mimic the structure of natural tissues.

XPS analysis confirmed that the alkali-treated surfaces did not include $\mathrm{Na}$ before or after heat treatments up to $800^{\circ} \mathrm{C}$. Furthermore, Kobayashi found that a graded surface consisting of a sodium titanate layer, sodium titanate dense film, $\mathrm{TiO}_{2}$ layer, and alloy substrate was formed during heat treatment at $600^{\circ} \mathrm{C}$ [21]. Considering the reappearance of the sodium titanium layer after heat treatment at $800^{\circ} \mathrm{C}$, Park reported that fewer oxides were present after heat treatment, which could lead to easier detection after treatment at high temperatures [22]. The XRD findings were in agreement with the results of conventional alkali-heat treatment and showed that the sodium hydrogen titanate was gradually transformed into amorphous sodium titanate and/or crystalline sodium titanate after heat treatment. When $\mathrm{NaOH}$-treated Ti metal is subjected to heat treatment at 400 $500^{\circ} \mathrm{C}$, its surface sodium titanite hydrogel layer is dehydrated and transformed into an amorphous sodium titanate at $600^{\circ} \mathrm{C}$; above $800^{\circ} \mathrm{C}$ it is converted into crystalline sodium titanate and rutile [7]. The results of this study clearly showed that heat treatment at $600^{\circ} \mathrm{C}$ was optimal for the formation of amorphous sodium titanate; this temperature has also been selected for use in alkali and heat treatment techniques for clinical applications.

Albumin and cell adhesion of rat BMMSCs, ALP activity, OCN production, and $\mathrm{Ca}$ deposition were measured to determine the biocompatibility of the modified titanium surface, a critical prerequisite for cell proliferation and differentiation. Albumin is the most abundant protein in plasma, and is known to discourage the adsorption of proteins that may stimulate inflammation and bacterial colonization [23]. In this study, the test group showed higher adsorption of albumin than the control group. The improvement of surface topography could be indirect; the adsorption of proteins or ions might act as a bridge between the nanostructured surface and cells. This increased surface area allows increased adhesion of cells such as osteoblasts and fibroblasts [24-26]. Adsorption of proteins can subsequently guide the adhesion of cells on the implant material surface, among other functions. Numerous studies have demonstrated improved cell adhesion and proliferation on nanostructured surfaces that could be beneficial for various tissue applications, including bladder, bone, vasculature, and nervous systems. A previous study indicated that TNSs on titanium surfaces help to regulate the osteoblastic differentiation of bone marrow cells and enhance mineralization. ALP activity, OCN production, and calcium deposition were all elevated by the presence of TNSs on the implant surface. Importantly, the functional phenotypes expressed in the middle and late stages of culture, such as ALP activity and mineralization, were considerably increased. Considerable research has shown that surface modification of implants can affect ALP activation [27-31]. Our results also support these conclusions. The observed increase of OCN production in the presence of the nanostructured surfaces is also in agreement with previous findings [32,33]. In general, chemical bonding between alkali- and heat-treated titanium alloy metals and bone via an apatite layer is thought to play a major role in bone-bonding behavior. Alkali- and heat-treated titanium implants have a thin reactive surface layer, resulting from the alkali and heat treatments. This layer can form apatite in SBF such as bioactive glasses and glass-ceramics, and this is also thought to occur in vivo. Apatite formation on the surface of the material is considered a prerequisite for direct bone bonding. Details of the mechanism underlying apatite formation on the surface of alkali- and heat-treatment titanium metals have been described by Kim et al. [7] Osteogenic cells may attach to the surfaces of alkali- and heat-treated titanium alloy implants themselves or to the apatite formed on their surfaces, and this may enhance growth and differentiation [34,35]. Once new bone forms, tight bonding between the bone and the alkali- and heat-treated titanium implant develops via the biological apatite in the bone and the bone-like apatite on the surface of the implant. This might explain the strong bonding between the bone and the alkali- and heat-treated titanium implants.

It has been shown that the apatite layer formed in vitro on a smooth titanium surface after $\mathrm{NaOH}$ and heat treatment has high adhesive capacity, although an in vivo assessment is necessary to further address the relationship between titanium and bone behavior. Therefore, considerable effort has been expended in developing new technologies to modify the surface of titanium to assist biointegration with bone.

\section{Conclusion}

Combined $\mathrm{NaOH}$ and heat treatment were used to produce a thin amorphous sodium titanate layer on a titanium surface. This surface provided optimal conditions for bone marrow cell adhesion and bone differentiation. Further development of advanced implant materials using nanotechnology could facilitate production of materials with improved osseointegration. 


\section{Acknowledgments}

We are grateful to the members of the Department of Removable Prosthodontics and Occlusion for their kind advice and assistance. This study was partly supported by an Oral Implant Research Grant (1602) from Osaka Dental University and a Grant-in-Aid for Scientific Research (15K11185, 16K20524) from the Japan Society for the Promotion of Science.

\section{Disclosure}

The authors report no conflicts of interest in this work.

\section{References}

1. Vandrovcová M, Bačáková L (2011) Adhesion, growth and differentiation of osteoblasts on surface-modified materials developed for bone implants. Physiol Res 60: 403-417. [Crossref]

2. Komasa S, Taguchi Y, Nishida H, Tanaka M, Kawazoe T (2012) Bioactivity of nanostructure on titanium surface modified by chemical processing at room temperature. J Prosthodont Res 56: 170-177. [Crossref]

3. Komasa S, Kusumoto T, Taguchi Y, Nishizaki H, Sekino T, Umeda M, Okazaki J, Kawazoe T (2014) Effect of nanosheet surface structure of titanium alloys on cell differentiation. J Nanomater 170 .

4. Xing H, Komasa S, Taguchi Y, Sekino T, Okazaki J (2014) Osteogenic activity of titanium surfaces with nanonetwork structures. Int J Nanomedicine 9: 1741-1755. [Crossref]

5. Homsy CA, Cain TE, Kessler FB, Anderson MS, King JW (1972) Porous implant systems for prosthesis stabilization. Clin Orthop Relat Res 89: 220-235. [Crossref]

6. Kim HM, Kokubo T, Fujibayashi S, Nishiguchi S, Nakamura T (2000) Bioactive macroporous titanium surface layer on titanium substrate. $J$ Biomed Mater Res 52 : 553-557. [Crossref]

7. Kim HM, Miyaji F, Kokubo T, Nakamura T (1997) Effect of heat treatment on apatiteforming ability of Ti metal induced by alkali treatment. J Mater Sci Mater Med 8: 341-347. [Crossref]

8. Nishio K, Neo M, Akiyama H, Nishiguchi S, Kim HM, et al. (2000) The effect of alkaliand heat-treated titanium and apatite-formed titanium on osteoblastic differentiation of bone marrow cells. J Biomed Mater Res 52: 652-661. [Crossref]

9. Nishiguchi S, Nakamura T, Kobayashi M, Kim HM, Miyaji F, et al. (1999) The effect of heat treatment on bone-bonding ability of alkali-treated titanium. Biomaterials 20: 491-500. [Crossref]

10. Pattanayak DK, Yamaguchi S, Matsushita T, Kokubo T (2011) Nanostructured positively charged bioactive $\mathrm{TiO} 2$ layer formed on $\mathrm{Ti}$ metal by $\mathrm{NaOH}$, acid and heat treatments. J Mater Sci Mater Med 22: 1803-1812. [Crossref]

11. Kim HM, Miyaji F, Kokubo T, Nakamura T (1996) Preparation of bioactive Ti and its alloys via simple chemical surface treatment. J Biomed Mater Res 32: 409-417. [Crossref]

12. Nishiguchi S, Nakamura T, Kobayashi M, Kim HM, Miyaji F, et al. (1999) The effect of heat treatment on bone-bonding ability of alkali-treated titanium. Biomaterials 20: 491-500. [Crossref]

13. Kokubo T, Miyaji F, Kim HM, Nakamura T (1996) Spontaneous Formation of Bonelike Apatite Layer on Chemically Treated Titanium Metals. JACerS.

14. Lin FH, Hsu YS, Lin SH, Sun JS (2002) The effect of Ca/P concentration and temperature of simulated body fluid on the growth of hydroxyapatite coating on alkalitreated 316L stainless steel. Biomaterials 23: 4029-4038. [Crossref]

15. Svanborg LM, Andersson M, Wennerberg A (2010) Surface characterization of commercial oral implants on the nanometer level. J Biomed Mater Res B Appl Biomater 92: 462-469. [Crossref]

16. Su Y, Komasa S, Sekino T, Nishizaki H, Okazaki J (2016) Nanostructured Ti6Al4V alloy fabricated using modified alkali-heat treatment: Characterization and cell adhesion. Mater Sci Eng C 59: 617-23.

17. Nishiguchi S, Nakamura T, Kobayashi M, Kim HM, Miyaji F, et al. (1999) The effect of heat treatment on bone-bonding ability of alkali-treated titanium. Biomaterials 20 : 491-500. [Crossref]

18. Lee BH, Do Kim Y, Shin JH, Hwan Lee K (2002) Surface modification by alkali and heat treatments in titanium alloys. J Biomed Mater Res 61: 466-473. [Crossref]

19. Xiong J, Li Y, Wang X, Hodgson P, Wen C (2008) Mechanical properties and bioactive surface modification via alkali-heat treatment of a porous $\mathrm{Ti}-18 \mathrm{Nb}-4 \mathrm{Sn}$ alloy for biomedical applications. Act Biomater 4: 1963-8.

20. Fujino T, Taguchi Y, Komasa S, Sekino T, Tanaka M (2014) Cell differentiation on nanoscale features of a titanium surface: Effects of deposition time in $\mathrm{NaOH}$ solution. J Hard Tissue Biol 23: 63-9.

21. Zhao L, Mei S, Chu PK, Zhang Y, Wu Z (2010) The influence of hierarchical hybrid micro/nano-textured titanium surface with titania nanotubes on osteoblast functions. Biomaterials 31: 5072-5082. [Crossref]

22. Kobayashi S, Inoue T, Nakai K (2005) Effect of heat treatment on cohesion of films on alkali-treated titanium. Mater Trans 46(2): 207-10.

23. Park JH, Lee DY, Kim KN (2004) Characterization of the surface oxide on thermally oxidized Ti6Al4V alloy for improvement of bioactivity. Abs. 1, 205th Meeting, The Electrochemical Society, Inc.

24. McFarland CD, De Filippis C, Jenkins M, Tunstell A, Rhodes NP, et al. (1998) Albuminbinding surfaces: in vitro activity. J Biomater Sci Polym Ed 9: 1227-1239. [Crossref]

25. Bell B, Schuler M, Tosatti S, Textor M, Schwartz Z, Boyan B (2011) Osteoblast response to titanium surfaces functionalized with extracellular matrix peptide biomimetics. Clin Oral Impl Res 22: 865-72.

26. Annunziata M, Oliva A, Buosciolo A, Giordano M, Guida A, et al. (2012) Bone marrow mesenchymal stem cell response to nano-structured oxidized and turned titanium surfaces. Clin Oral Implants Res 23: 733-740. [Crossref]

27. Meirelles L, Currie F, Jacobsson M, Albrektsson T, Wennerberg A (2008) The effect of chemical and nanotopographical modifications on the early stages of osseointegration. Int J Oral Maxillofac Implants 23: 641-647. [Crossref]

28. Schwartz Z, Lohmann CH, Oefinger J, Bonewald LF, Dean DD, et al. (1999) Implant surface characteristics modulate differentiation behavior of cells in the osteoblastic lineage. Adv Dent Res 13: 38-48. [Crossref]

29. Takeuchi K, Saruwatari L, Nakamura HK, Yang JM, Ogawa T (2005) Enhanced intrinsic biomechanical properties of osteoblastic mineralized tissue on roughened titanium surface. J Biomed Mater Res A 72: 296-305.

30. Att W, Hori N, Iwasa F, Yamada M, Ueno T, et al. (2009) The effect of UVphotofunctionalization on the time-related bioactivity of titanium and chromium-cobalt alloys. Biomaterials 30: 4268-4276. [Crossref]

31. Dalby MJ, McCloy D, Robertson M, Agheli H, Sutherland D, et al. (2006) Osteoprogenitor response to semi-ordered and random nanotopographies. Biomaterials 27: 2980-2987. [Crossref]

32. Göransson A, Arvidsson A, Currie F, Franke-Stenport V, Kjellin P, Mustafa K, et al. (2009) An in vitro comparison of possibly bioactive titanium implant surfaces. $J$ Biomed Mater Res A 88: 1037-47.

33. Li P, de Groot K (1993) Calcium phosphate formation within sol-gel prepared titania in vitro and in vivo. J Biomed Mater Res 27: 1495-1500. [Crossref]

34. Kim HM, Miyaji F, Kokubo T, Nishiguchi S, Nakamura T (1999) Graded surface structure of bioactive titanium prepared by chemical treatment. $J$ Biomed Mater Res 45: 100-107. [Crossref]

35. Yang B, Uchida M, Kim HM, Zhang X, Kokubo T (2004) Preparation of bioactive titanium metal via anodic oxidation treatment. Biomaterials 25: 1003-1010. [Crossref]

Copyright: (C2017 Fujio M. This is an open-access article distributed under the terms of the Creative Commons Attribution License, which permits unrestricted use, distribution, and reproduction in any medium, provided the original author and source are credited. 